\title{
IMPLEMENTASI PEMBELAJARAN INKUIRI TERBIMBING TIPE PICTORIAL RIDDLE BERBANTUAN KR-CHART UNTUK MENINGKATKAN KREATIVITAS DAN PRESTASI BELAJAR SISWA PADA MATERI LARUTAN PENYANGGA KELAS XI IPA SMA NEGERI 1 NGEMPLAK BOYOLALI TAHUN PELAJARAN 2017/2018
}

\author{
Vashti Dea Pavita, Suryadi Budi Utomo*, dan Ashadi \\ Program Studi Pendidikan Kimia, FKIP, Universitas Sebelas Maret, Surakarta, Indonesia \\ “Keperluan Korespondensi, HP: 081548781644 , email: sbukim98@staff.uns.ac.id
}

\begin{abstract}
ABSTRAK
Penelitian ini bertujuan untuk meningkatkan: (1) kreativitas siswa dan (2) prestasi belajar siswa pada materi larutan penyangga kelas XI IPA SMA Negeri 1 Ngemplak Boyolali tahun pelajaran 2017/2018 dengan implementasi pembelajaran Inkuiri Terbimbing tipe Pictorial Riddle berbantuan KR-Chart. Penelitian ini merupakan penelitian tindakan kelas (PTK) yang dilaksanakan dalam 2 siklus. Setiap siklus terdiri atas perencanaan, pelaksanaan tindakan, observasi tindakan, serta refleksi. Subjek penelitian adalah siswa kelas XI IPA 5 SMA N 1 Ngemplak Boyolali tahun pelajaran 2017/2018. Teknik pengumpulan data melalui observasi, wawancara, kajian dokumen, tes, dan angket. Teknik analisis yang digunakan adalah deskriptif kualitatif. Hasil penelitian ini menunjukkan bahwa: (1) Implementasi pembelajaran Inkuiri Terbimbing tipe Pictorial Riddle berbantuan KR-Chart dapat meningkatkan kreativitas siswa pada materi pokok larutan penyangga kelas XI IPA SMA Negeri 1 Ngemplak Boyolali tahun pelajaran 2017/2018, (2) Implementasi pembelajaran Inkuiri Terbimbing tipe Pictorial Riddle berbantuan $K R$-Chart dapat meningkatkan prestasi belajar siswa pada materi pokok larutan penyangga kelas XI IPA SMA Negeri 1 Ngemplak Boyolali tahun pelajaran 2017/2018.
\end{abstract}

Kata Kunci: inkuiri terbimbing, pictorial riddle, KR-Chart, kreativitas, prestasi belajar, larutan penyangga.

\section{PENDAHULUAN}

Pendidikan adalah usaha sadar dan terencana untuk mewujudkan suasana belajar dan proses pembelajaran agar peserta didik secara aktif mengembangkan potensi dirinya untuk memiliki kekuatan spiritual keagamaan, pengendalian diri, kepribadian, kecerdasan, akhlak mulia, serta keterampilan yang diperlukan dirinya, masyarakat, bangsa dan negara [1]. Proses pendidikan mengarah pada proses berfungsinya potensi peserta didik secara manusiawi supaya mereka dapat menjadi diri mereka sendiri yang memiliki kemampuan serta kepribadian yang unggul [2]. Kualitas hasil pendidikan hingga saat ini masih tetap menjadi masalah yang penting dalam setiap pembaharuan pada sistem pendidikan.

Dalam rangka mewujudkan tujuan pendidikan nasional, pemerintah selalu melakukan upaya pembaharuan pendidikan yang berkaiatan dengan beberapa jenis inovasi pendidikan, salah satunya adalah inovasi di bidang kurikulum [3]. Kurikulum 2013 menjanjikan terlahirnya generasi penerus bangsa yang kreatif, inovatif, produktif dan juga berkarakter. Dengan adanya kreativitas, para anak bangsa dapat berinovasi secara produktif dalam menjawab tantangan di masa depan yang semakin kompleks [4].

SMA N 1 Ngemplak adalah satu di antara sekolah menengah atas yang berada di wilayah Boyolali. Dari hasil wawancara, kurikulum di sekolah ini 
menggunakan kurikulum 2013. Namun pada kenyataannya berdasarkan hasil observasi peneliti pada saat melakukan Magang Kependidikan 3, masih terdapat banyak guru yang belum mengimplementasikan pembelajaran yang mengacu Kurikulum 2013. Pembelajaran yang berpusat pada guru masih mendominasi dalam proses pembelajaran di kelas. Keadaan yang seperti ini membuat siswa mudah jenuh dalam pelajaran. Pola pembelajaran yang berpusat pada guru pada dasarnya telah menyimpang dari hakikat pembelajaran karena pola pembelajaran yang benar ialah pola pembelajaran yang berpusat pada peserta didik [5].

Berdasarkan observasi peneliti, kimia adalah salah satu pelajaran yang dianggap sulit oleh siswa. Belajar dalam ilmu kimia adalah suatu proses yang kompleks, karena siswa tidak hanya belajar tentang zat yang bermanfaat atau zat yang berbahaya bagi manusia, namun belajar kimia meliputi segala hal yang berkaitan dengan struktur, komposisi, sifat, serta perubahan zat yang melibatkan ketrampilan dan penalaran. Hasil observasi kegiatan pembelajaran kimia di SMA Negeri 1 Ngemplak Boyolali didukung dengan data wawancara guru kimia kelas XI IPA diperoleh bahwa pembelajaran menggunakan metode ceramah dan diskusi, dalam pelaksanaan pembelajaran tersebut siswa masih belum cukup aktif. Bagi siswa dengan kemampuan menengah ke atas materi dapat diterima dengan baik, namun untuk siswa yang berkemampuan menengah ke bawah masih sulit menerima materi yang dijelaskan.

Dari segi kreativitas, guru mengakui bahwa kreativitas siswa disana masih sangat rendah yang dapat dilihat dari kemampuan siswa saat menger-jakan soal, dimana siswa masih kesuli-tan dalam mengidentifikasi aspek-aspek yang diketahui dan masih kesulitan dalam menentukan langkah-langkah megerjakan soal. Oleh karena itu, hasil pencapaian pembelajaran masih kurang maksimal dimana masih banyak terdapat nilai ulangan tengah semester yang dibawah KKM (Kriteria Ketuntasan Minimum) yaitu 70 .
Hasil belajar kimia Kelas XI IPA di SMA Negeri 1 Ngemplak Boyolali bisa dilihat dari rata-rata nilai UTS murni mata pelajaran kimia semester ganjil tahun pelajaran 2017/2018 yang disajikan dalam Tabel 1 berikut.

Tabel 1. Rata-rata Nilai UTS Kimia Semester Ganjil SMA Negeri 1 Ngemplak Boyolali Tahun Ajaran 2017/2018

\begin{tabular}{ccc}
\hline No & Kelas & $\begin{array}{c}\text { Nilai Rata-rata } \\
\text { UTS Kimia }\end{array}$ \\
\hline 1. & XI IPA 1 & 63 \\
2. & XI IPA 2 & 57 \\
3. & XI IPA 3 & 68 \\
4. & XI IPA 4 & 58 \\
5. & XI IPA 5 & 56 \\
\hline
\end{tabular}

Sumber: Dokumen Guru Mata Pelajaran Kimia SMA Negeri 1 Ngemplak Boyolali

Materi yang seringkali dianggap susah oleh siswa di dalam mata pelajaran kimia salah satunya adalah larutan penyangga. Berdasarkan wawancara dari guru kimia yang mengajar materi larutan penyangga, siswa mengalami kesulitan dalam mengidentifikasi pertanyaan dalam soal terkait penggunaan rumus untuk mencari nilai $\mathrm{pH}$ apakah menggunakan rumus $\mathrm{pH}$ asam lemah, asam kuat, basa lemah, basa kuat atau penyangga. Selain itu siswa belum sepenuhnya paham terhadap satuan-satuan, seperti satuan volume dan massa. Contohnya jika dalam soal diketahui volume, siswa seringkali menganggapnya sama dengan massa dimana nantinya dalam mengerjakan soal menggunakan rumus mol sebagai perbandingan massa dan massa atom relatif, bukan mengkonversikan volume ke dalam massa terlebih dahulu. Untuk dapat memahami materi larutan penyangga, siswa diharapkan mampu mempergunakan pola pikir yang sistematis dan terstruktur melalui tahap-tahap pemecahan soal yang tepat. Dibutuhkan kecakapan siswa dalam mengembangkan krea-tivitas sehingga siswa benar-benar memahami materi larutan penyangga.

Kesulitan pelajaran kimia pada materi larutan penyangga ditunjukkan 
dengan nilai harian siswa pada Tabel 2 sebagai berikut :

Tabel 2. Ketuntasan Siswa pada Materi Larutan Penyangga Semester Genap SMA Negeri 1 Ngemplak Boyolali Tahun Pelajaran 2016/ 2017

\begin{tabular}{cccc}
\hline Kelas & KKM & $\begin{array}{c}\text { Total } \\
\text { Siswa }\end{array}$ & $\begin{array}{c}\text { Ketun- } \\
\text { tasan } \\
(\%)\end{array}$ \\
\hline XI IPA 1 & 70 & 36 & 50 \\
XI IPA 2 & 70 & 36 & 44 \\
XI IPA 3 & 70 & 36 & 28 \\
XI IPA 4 & 70 & 36 & 30 \\
\hline
\end{tabular}

Sumber: Dokumen Guru Mata Pelajaran Kimia SMA Negeri 1 Ngemplak Boyolali

Berdasarkan uraian di atas, maka peneliti ingin melakukan Penelitian Tindakan Kelas (PTK) sebagai langkah perbaikan pembelajaran sehingga tujuan pembelajaran dapat tercapai dengan maksimal. Pada Penelitian Tindakan Kelas (PTK) ini, peneliti mencoba menerapkan suatu model pembelajaran yang melibatkan keaktifan siswa dalam mengembangkan kemampuan berpikir kreatif siswa dalam mempelajari ilmu kimia khususnya pada materi pokok larutan penyangga, yaitu dengan model pembelajaran inkuiri terbimbing tipe pictorial riddle ber-bantuan key relation chart.

Berdasarkan penelitian yang sebelumnya, telah dibuktikan bahwa penerapan model pembelajaran scientific inquiry berbasis pictorial riddle mampu meningkatkan prestasi belajar siswa dalam pelajaran fisika [5]. Oleh karena itu peneliti terdorong untuk memakai model pembelajaran inkuiri terbimbing tipe pictorial riddle guna diterapkan pada pembelajaran kimia khususnya pada materi pokok larutan penyangga. Langkah ini diharapkan mampu meningkatkan prestasi belajar siswa pada materi pokok larutan penyangga.

Dalam penelitian ini, peneliti menggunakan inkuiri terbimbing bukan menggunakan inkuiri bebas karena disesuaikan dengan kemampuan siswa, dimana guru memberikan kesempatan bimbingan dan petunjuk yang lebih luas kepada siswa. Seorang guru yang menggunakan metode inkuiri terbimbing memberikan ceramah minimal untuk mengenalkan gagasan dan memberikan ikhtisar namun menggunakan lebih banyak pertanyaan dan kegiatan kelas yang interaktif untuk merangsang dan berbagi gagasan [6].

Pictorial riddle sendiri adalah salah satu metode untuk mengem-bangkan minat siswa di dalam diskusi kelompok kecil ataupun besar. Alasan peneliti menggunakan pictorial riddle adalah karena pembelajaran kimia tidak terlepas dari gambar. Gambar atau peraga dapat digunakan untuk me-ngembangkan cara berfikir siswa secara kreatif. Suatu riddle dapat berupa gambar di papan poster, papan tulis, atau diproyeksikan melalui suatu transparansi, setelah itu guru menga-jukan pertanyaan-pertanyaan yang berkaitan dengan riddle tersebut [7].

Selain penerapan model pembelajaran yang sesuai, kreativitas juga dapat ditunjang melalui peng-gunaan media pembelajaran. Key Relation Chart (KR-Chart) merupakan lembaran yang berisi rumus, persamaan dan hukum dari materi serta memperlihatkan hubungan antar informasi. Hubungan antar informasi menciptakan pengetahuan baru yang ditemukan sendiri oleh peserta didik [8]. Media KR-Chart dapat memudahkan siswa dalam mengingat hubungan yang diperlukan dalam menyelesaikan masalah [9].

Dari penggunaan media KR-Chart siswa dituntut untuk dapat menyusun komponen, mencari relasi kunci, dan memberi keterangan komponen-komponen pada KR-Chart terkait materi pokok larutan penyangga sehingga dapat meningkatkan kreativitas siswa dalam pelajaran larutan penyangga. Berdasarkan hasil penelitian sebelumnya, media key relation chart dalam pembelajaran mendorong siswa untuk lebih berkreasi [10]. Dengan demikian dengan penggunaan media key relation chart pada penelitian ini diharapkan dapat meningkatkan kreativitas siswa.

Dari uraian latar belakang permasalahan di atas, maka perlunya mengetahui sejauh mana penerapan 
model pembelajaran inkuiri terbimbing tipe pictorial riddle berbantuan KR-Chart dalam meningkatkan kreativitas dan prestasi belajar siswa khususnya pada materi pokok larutan penyangga. Melalui penelitian Tindakan Kelas (PTK) ini maka penulis mengadakan penelitian yang berjudul "Implementasi Pem-belajaran Inkuiri Terbimbing Tipe Pictorial Riddle Berbantuan $\mathrm{Kr}$-Chart untuk Meningkatkan Kreativitas dan Prestasi Belajar Siswa pada Materi Larutan Penyangga Kelas XI IPA SMA Negeri 1 Ngemplak Boyolali."

\section{METODE PENELITIAN}

Penelitian ini merupakan Penelitian Tindakan Kelas (PTK) yang dilaksanakan dalam dua siklus. Rancangan solusi permasalahan yakni dengan menggunakan model Inkuiri Terbimbing Tipe Pictorial Riddle Berbantuan KRChart dengan tujuan untuk meningkatkan kreativitas dan prestasi belajar siswa pada materi larutan penyangga.

Subjek penelitian adalah siswa kelas XI IPA 5 semester genap SMA Negeri 1 Ngemplak Boyolali tahun pelajaran 2017/2018. Pemilihan subjek dalam penelitian ini didasarkan pada pertimbangan, yaitu subjek tersebut memiliki permasalahan-permasalahan yang telah teridentifikasi pada saat observasi awal. Objek penelitian ini adalah kualitas proses dan prestasi belajaar siswa.kualitas proses yang dimaksud adalah kreativitas siswa dalam pembelajaran. Sedangkan prestasi belajar yang dimaksud adalah ketuntasan siswa dalam pembelajaran yang diterapkan.

Data yang dikumpulkan dalam penelitian ini meliputi data informasi tentang keadaan siswa dilihat dari aspek kualitatif dan kuantitatif. Aspek kualitatif berupa kajian dokumen atau arsip, data hasil observasi, dan wawancara yang menggambarkan proses pembelajaran di kelas serta kesulitan yang dialami guru dalam mengajar di kelas dan dalam menghadapi siswa . sedangkan aspek kuantitatif yang dimaksud adalah hasil penilaian belajar dari materi pembelajaran larutan penyangga berupa aspek kognitif, sikap, keterampilan, dan kreativitas siswa pada materi larutan penyangga. Teknik analisis data mengacu pada model analisis Miles dan Huberman yang meliputi tiga komponen yaitu reduksi data, penyajian data, penarikan kesimpulan dan verifikasi [11].

\section{HASIL DAN PEMBAHASAN}

Penelitian tindakan kelas ini bertujuan untuk meningkatkan kreativitas dan prestasi belajar siswa kelas XI IPA SMA Negeri 1 Ngemplak Boyolali pada materi larutan penyangga dengan penerapan pembelajaran inkuiri terbimbing tipe pictorial riddle berbantuan KR-Chart. Prestasi belajar siswa meliputi aspek pengetahuan, sikap, dan keterampilan.

Penelitian ini dilakukan selama dua siklus yaitu siklus I dan siklus II. Siklus I dilaksanakan selama 4 perte-muan (8JP) dan Siklus II dilak-sanakan selama 3 pertemuan (6JP). Setiap siklus terdiri dari perencanaan tindakan, pelaksanaan tindakan, observasi tindakan dan refleksi tindakan. Proses pembelajaran dilakukan dalam kelompok agar terjadi kerjasama antar siswa dan mendorong siswa untuk berpikir kreatif. Pusat pembelajaran adalah siswa dan guru berperan sebagai fasilitator dan motivator.

Berdasarkan observasi prasiklus yang dilakukan di kelas XI IPA 5 SMA Negeri 1 Ngemplak tahun pelajaran 2017/2018 menunjukkan bahwa kreativitas siswa sebesar 32\%. Dari hasil observasi tersebut menunjukkan bahwa kreativitas siswa masih rendah.

\section{Siklus I}

Tahap perencanaan tindakan siklus 1 diawali dengan menyusun instrumen pembelajaran berupa silabus, Rencana Pelaksanaan Pembelajaran (RPP), dan instrumen evaluasi pembelajaran yang meliputi aspek kreativitas pengetahuan, sikap, dan keterampilan. Pembelajaran pada siklus I dialokasikan selama 8 jam pelajaran (4 kali tatap muka), yang terdiri dari $6 \times 45$ menit ( 3 kali tatap muka) untuk penyampaian materi dan $2 \times 45$ menit untuk kegiatan evaluasi. Seluruh instrumen sebelum 
digunakan, divalidasi terlebih dahulu oleh dua panelis.

Untuk mendukung penerapan model pembelajaran Inkuiri Terbimbing Tipe Pictorial Riddle berbantuan KRChart, 38 siswa di kelas XI IPA 5 dibagi menjadi 7 kelompok dengan masingmasing kelompok terdiri dari 5-6 siswa. Berikut adalah hasil evaluasi pembelajaran yang meliputi aspek kretaivitas, pengetahuan, sikap, dan keterampilan.

\section{a. Kreativitas}

Penilaian kreativitas dilakukan dengan menggunakan tes kemampuan verbal. Adapun diagram pie ketercapaian aspek kreativitas siswa kelas XI IPA 5 siklus I dapat dilihat pada Gambar 1.

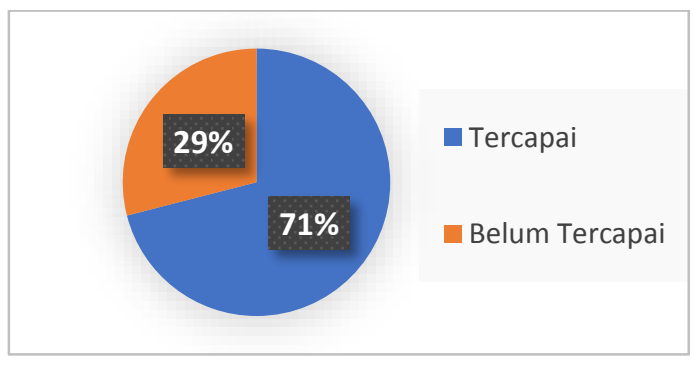

Gambar 1. Ketercapaian Aspek Kreativitas Siswa kelas XI IPA 5 Siklus I

Berdasarkan hasil analisis diketahui bahwa dari 38 siswa kelas XI IPA 5, 27 siswa atau $71 \%$ mencapai target yang telah ditentukan dan 11 siswa atau $29 \%$ belum mencapai target. Dari gambar di atas diperoleh hasil bahwa persentase ketercapaian aspek kreativitas pada siklus I sebesar $71 \%$ Hasil ini telah mencapai target penelitian yaitu $70 \%$. Hal ini menunjukkan bahwa kreativitas siswa pada siklus I ini telah mengalami peningkatan dari kondisi awal. Walaupun pada siklus I ini aspek kreativitas telah mencapai target, namun pada akhir siklus II nanti akan dilakukan tes kreativitas kembali. Hal ini dilakukan bertujuan untuk mengetahui ada atau tidaknya peningkatan kreati-vitas siswa dari siklus I ke siklus II.

\section{b. Pengetahuan}

Pada kegiatan evaluasi di akhir siklus I, dilakukan penilaian pengetahuan melalui tes. Tes pengetahuan terdiri dari 20 soal pilihan ganda dengan 6 Indikator Kompetensi, yaitu (1) Mendefinisikan larutan pe-nyangga; (2) Mengidentifikasi komposisi jenis-jenis larutan penyangga; (3) Menghitung $\mathrm{pH}$ larutan penyangga asam dan larutan penyangga basa; (4) Menjelaskan prinsip kerja larutan penyangga.; (5) Menghitung $\mathrm{pH}$ larutan penyangga dengan menambahkan sedikit asam atau sedikit basa atau dengan pengenceran; dan (6) Menjelas-kan fungsi larutan penyangga dalam kehidupan sehari-hari. Adapun diagram pie ketercapaian aspek pengetahuan siswa kelas XI IPA 5 siklus I dapat dilihat pada Gambar 2.

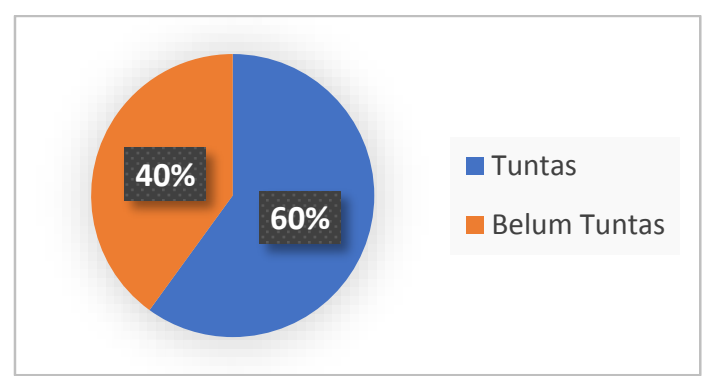

Gambar 2. Ketercapaian Aspek Pengetahuan Siswa kelas XI IPA 5 Siklus I

Berdasarkan hasil evaluasi siklus I diketahui bahwa hasil ketuntasan siswa kelas XI IPA 5 SMA Negeri 1 Ngemplak Boyolali pada materi larutan penyangga sebesar $60 \%$, yaitu sebanyak 23 dari 38 siswa sudah mencapai target ketuntasan dan 15 siswa belum tuntas. Dari 6 indikator masih terdapat 2 indikator yang belum mencapai target yaitu indikator nomor 3 dan 5. Dapat diketahui bahwa dua indikator tersebut adalah materimateri yang cenderung pada perhitungan, hal ini dikarenakan siswa kurang teliti dalam menghitung. Oleh karena itu pada siklus II perlu adanya penekanan pada materi-materi yang menuntut banyak perhitungan untuk mencapai target penelitian.

\section{c. Sikap}

Aspek sikap dinilai melalui angket dan observasi. Apabila terjadi perbedaan pada hasil observasi dan angket, maka perlu dilakukan wawancara. Berdasarkan hasil analisis penilaian sikap, diketahui bahwa dari 38 siswa 
kelas XI IPA 5, 10 siswa mendapat kategori SB (sangat baik), 25 siswa mendapat kategori B (baik), dan 3 siswa mendapat kategori C (cukup). Adapun diagram pie ketercapaian aspek sikap siklus I dapat dilihat pada Gambar 3.

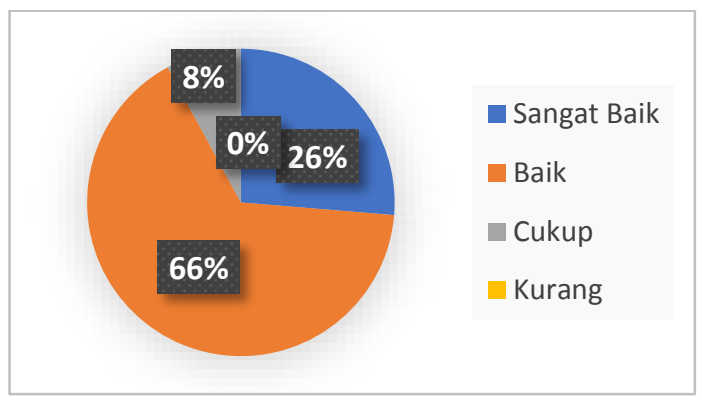

Gambar 3. Hasil Akhir Ketercapain Aspek Sikap Siklus I

Dari diagram pie di atas diketahui bahwa siswa dengan kategori SB (sangat baik) sebanyak 10 anak atau $26 \%$, siswa dengan kategori sikap $\mathrm{B}$ (baik) sebesar 25 anak atau $66 \%$, siswa dengan kategori sikap C (cukup) sebanyak 3 anak atau $8 \%$, dan tidak ada siswa dengan kategori sikap $\mathrm{K}$ (kurang) sehingga $0 \%$. Jadi dapat disimpulkan bahwa siswa yang tuntas pada aspek sikap melalui penilaian angket ini sebesar 92\%, yaitu akumulasi dari persentase siswa dengan kategori sikap baik dan sangat baik. Itu berarti aspek sikap sudah mencapai target yaitu $75 \%$. $\mathrm{Hal}$ ini disebabkan siswa memang cenderung mematuhi peraturan pembelajaran dengan baik sehingga pencapaian prestasi belajar siswa dalam aspek sikap pada siklus I ini pun langsung mencapai target.

\section{d. Keterampilan}

Aspek keterampilan yang dinilai dalam penelitian ini adalah keterampilan dalam presentasi. Berdasarkan analisis diketahui bahwa semua indikator pada aspek keterampilan sudah mencapai target yaitu $75 \%$. Ketuntasan aspek keterampilan pada kelas XI IPA 5 adalah sebesar $87 \%$ yaitu dari 38 siswa sebanyak 35 siswa tuntas. Adapun diagram pie persentase ketuntasan keterampilan siklus I dapat dilihat pada Gambar 4.

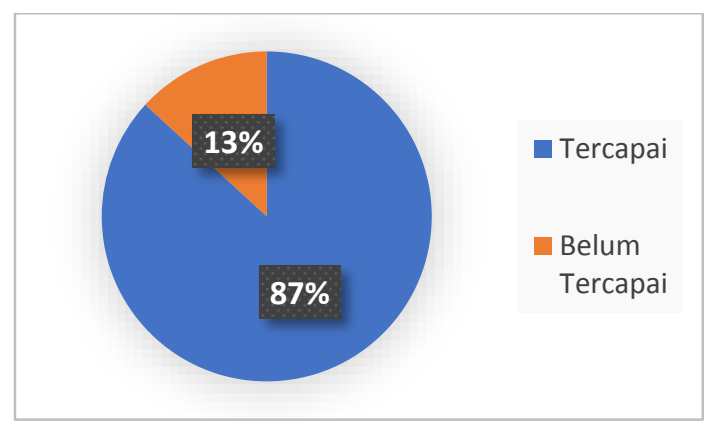

Gambar 4. Ketercapaian Aspek Keterampilan Siswa Kelas XI IPA 5 Siklus I

Penilaian aspek keterampilan hanya dilakukan pada siklus I karena keterbatasan waktu yang diberikan oleh pihak sekolah. Selain hal itu hasil yang diperoleh pada siklus I sudah mencapai target yang ditentukan sehingga tidak diulang lagi pada siklus II.

\section{Siklus II}

Perencanaan tindakan pada siklus II didasarkan pada hasil refleksi siklus I. Tindakan pada siklus II ini lebih difokuskan untuk memperbaiki kendalakendala yang muncul pada siklus I. Tindakan yang dimaksud yaitu memberikan materi yang fokus pada indikatorindikator yang belum tercapai ketuntasannya pada siklus I. Rancangan Pelaksanaan Pembelajaran (RPP) siklus II terdiri dari 2 kali tatap muka (4 $\times 45$ menit) untuk penguatan materi dan 1 kali pertemuan $(2 \times 45$ menit) untuk evaluasi pembelajaran siklus II.

Pada perbaikan siklus II ini guru lebih fokus pada siswa-siswa yang belum tuntas pada evaluasi siklus I. Selain itu guru juga memberi penegasan pada siswa untuk aktif dalam bertanya dan memberikan pendapat serta memberikan bimbingan secara intensif kepada setiap kelompok saat berlang-sungnya diskusi. Selain itu dalam rangka perbaikan, pada siklus II ini juga dilakukan penggantian anggota kelom-pok diskusi dimana pembagian ke-lompok ini didasarkan pada nilai yang telah dicapai siswa pada evaluasi pembelajaran siklus I. Berikut adalah hasil evaluasi pembelajaran siklus II. 


\section{a. Kreativitas}

Berdasarkan hasil analisis, diketahui bahwa ketercapaian pada aspek kreativitas di Siklus II ini sebesar $79 \%$. Adapun diagram pie ketercapaian aspek kreativitas siswa kelas XI IPA 5 siklus II dapat dilihat pada Gambar 5 .

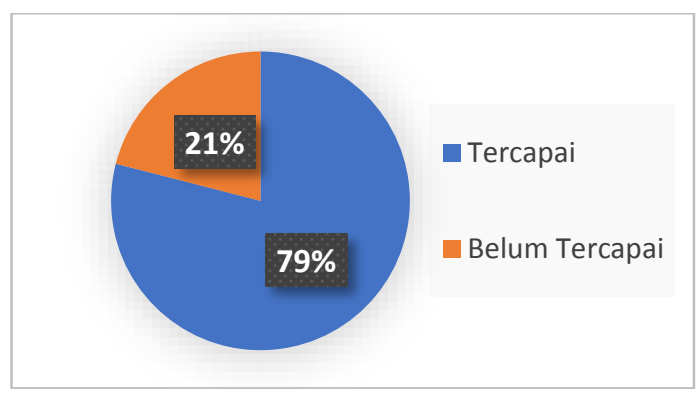

Gambar 5. Ketercapaian Aspek Kreativitas Siswa kelas XI IPA 5 Siklus II.

Dari diagram di atas diketahui dari 38 siswa kelas XI IPA 5, 30 siswa atau $79 \%$ mencapai target dan 8 siswa atau $21 \%$ belum mencapai.. $\mathrm{Hal}$ ini menunjukkan bahwa aspek kreativitas pada siklus II sudah mencapai target yaitu $70 \%$. Hasil yang dicapai pada siklus II mengalami peningkatan dari siklus I yaitu dari $71 \%$ menjadi $79 \%$.

\section{b. Pengetahuan}

Penilaian aspek pengetahuan pada siklus II diukur melalui tes. Tes pengetahuan terdiri dari 9 soal pilihan ganda dengan 2 Indikator kompetensi yang belum mencapai target pada siklus I. Berdasarkan hasil evaluasi siklus II diketahui bahwa hasil ketuntasan aspek pengetahuan siswa kelas XI IPA 5 SMA Negeri 1 Ngemplak pada materi larutan penyangga sebesar $84 \%$, yaitu sebanyak 32 siswa tuntas dan 6 siswa belum tuntas.

Untuk mengetahui presentasenya adapun diagram pie keterapaian aspek pengetahuan siklus II dapat dilihat pada Gambar 6 sebagai berikut

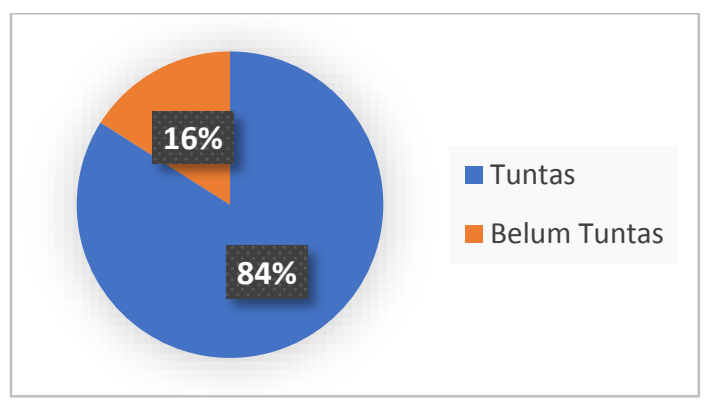

Gambar 6. Ketercapaian Aspek Pengetahuan Siklus II

Berdasarkan gambar di atas ini berarti bahwa aspek pengetahuan pada siklus II telah mencapai target yang telah ditentukan yaitu $70 \%$. Oleh karena itu tidak perlu adanya siklus berikutnya.

\section{c. Sikap}

Berdasarkan hasil analisis penilaian sikap siklus II, diketahui bahwa dari 38 siswa kelas XI IPA 5, 16 siswa atau $42 \%$ mendapat kategori SB (sangat baik), 20 siswa atau 53\% mendapat kategori B (baik), dan 2 siswa atau 5\% mendapat kategori C (cukup). Adapun diagram pie ketercapaian aspek sikap siklus II dapat dilihat pada Gambar 7.

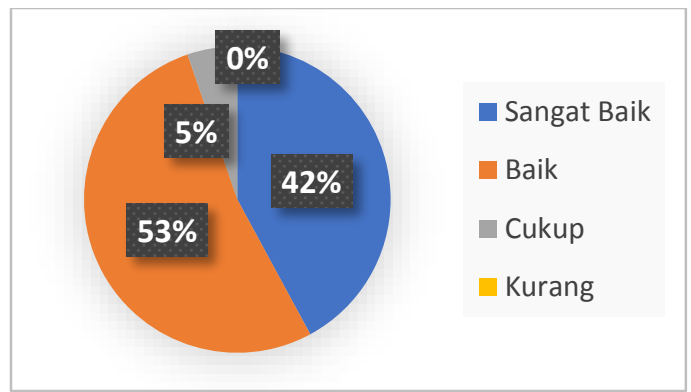

Gambar 7. Hasil Akhir Ketercapain Aspek Sikap Siklus II

Dari diagram pie di atas diketahui bahwa bahwa siswa yang tuntas pada aspek sikap siklus II sebesar $95 \%$, yaitu akumulasi dari persentase siswa dengan kategori sikap baik dan sangat baik. Hasil ini mengalami peningkatan dari hasil pada siklus I. 


\section{Perbandingan Hasil Tindakan Antar Siklus}

Perbandingan hasil tindakan antar siklus dapat digunakan untuk mengetahui peningkatan hasil dan proses belajar selama tindakan siklus I dan siklus II. Perbandingan hasil tindakan antar siklus disajikan dalam Tabel 3 berikut.

Tabel 3. Perbandingan Hasil Tindakan antar siklus Materi Pokok Larutan Penyangga Kelas XI IPA 5 SMA Negeri 1 Ngemplak Boyolali Tahun Pelajaran 2017/2018.

\begin{tabular}{|c|c|c|c|}
\hline \multirow[b]{2}{*}{ Aspek } & \multicolumn{2}{|c|}{ Capaian (\%) } & \multirow[b]{2}{*}{ Keterangan } \\
\hline & $\underset{\mid}{\text { Siklus }}$ & Siklus & \\
\hline $\begin{array}{c}\text { Kreati- } \\
\text { vitas }\end{array}$ & 71 & 79 & Meningkat \\
\hline $\begin{array}{l}\text { Penge- } \\
\text { tahuan }\end{array}$ & 60 & 84 & Meningkat \\
\hline Sikap & 92 & 95 & Meningkat \\
\hline
\end{tabular}

Berdasarkan observasi dan evaluasi yang telah dilakukan selama proses pembelajaran dengan model Inkuiri Terbimbing tipe Pictorial Riddle berbantuan KR-Chart pada siklus I dan siklus II diperoleh data yang menunjukkan ketercapaian aspek kreativitas dan prestasi belajar siswa pada materi larutan penyangga. Berdasarkan Tabel 1 diatas dapat diketahui adanya peningkatan dari siklus I ke siklus II. Pada siklus II aspek pengetahuan dapat mencapai target yang diinginkan. Hal ini didukung oleh hasil penelitian sebelumnya yang menyatakan bahwa pembelajaran menggunakan Inkuiri Terbimbing dapat meningkatkan prestasi belajar siswa di bidang sains. Untuk aspek kreativitas dan sikap juga mengalami peningkatan. Dalam penelitian tindakan kelas, suatu penelitian dinyatakan berhasil apabila masing-masing aspek yang diukur telah mencapai target yang telah ditetapkan [12].

Hasil penelitian ini didukung jurnal yang menyatakan bahwa pembelajaran dengan inkuiri terbimbing terhadap kreativitas memberikan pengaruh pada perolehan nilai hasil belajar yang lebih baik [13]. Selain itu hasil penelitian ini juga didukung oleh penelitian sebelumnya bahwa penggunaan media $K R$ Chart pada metode pembelajaran Think Pair Share (TPS) menghasilkan prestasi belajar yang lebih baik dibandingkan dengan menggunakan media LKS baik dari itu aspek kognitif maupun afektif pada materi Termokimia. Hal ini dikarenakan media KR-Chart dikemas secara lebih menarik [14].

\section{KESIMPULAN}

Berdasarkan hasil penelitian yang telah dilakukan, dapat disimpulkan bahwa penerapan pembelajaran inkuiri terbimbing tipe pictorial riddle berbantuan KR-Chart dapat meningkatkan kreativitas dan prestasi belajar siswa pada materi kelarutan penyangga kelas kelas XI IPA 5 SMA Negeri 1 Ngemplak Boyolali tahun pelajaran 2017/2018.

\section{UCAPAN TERIMA KASIH}

Terima kasih peneliti ucapkan kepada Stefanus Kristianto S.Pd selaku guru mata pelajaran Kimia SMA Negeri 1 Ngemplak Boyolali, siswa kelas XI IPA 5 SMA Negeri 1 Ngemplak Boyolali serta seluruh pihak yang turut berperan dalam penelitian ini.

\section{DAFTAR RUJUKAN}

[1] Undang-Undang Nomor 20 Tahun 2003 Tentang Sistem Pendidikan Nasional. Jakarta: Departemen Pendidikan Nasional Republik Indonesia.

[2] Mulyasana, D. (2011). Pendidikan Bermutu dan Berdaya Saing. Bandung : PT. Remaja Rosdakarya.

[3] Susanti, E., Yurnetti \& Ramli, E. (2015). Pillar of Physics Education, 5. 57-64.

[4] Mulyasa, H. E. (2013). Pengembangan dan Implementasi Kurikulum 2013. Bandung : PT. Remaja Rosdakarya. 
[5] Rahayu, S. F., Sriyono, \& Nurhidayati. (2015). Jurnal Radiasi. 6(1). 92-95.

[6] Onwuachu, Chidimma, W. \& Kanayo, C. (2015). Journal of Research in Pure and Applied Sciences. 5(1). 40-48.

[7] Rahayu, S. F., Sriyono, \& Nurhidayati. (2015). Jurnal Radiasi. 6(1). 92-95.

[8] Susanti, E., Yurnetti \& Ramli, E. (2015). Pillar of Physics Education . 5. 57-64.

[9] Susanti, A.T., Prayitno, B.A. \& Sudarisman, S. (2015). Jurnal Pendidikan Biologi. 7(2). 28-40.
[10] Nurhayati, Sudarmin, Mahatmanti F. W. \& Khodijah F. D. (2009). Jurnal Inovasi Pendidikan Kimia. 3(1). 379-384.

[11] Sugiyono. (2015). Metode Penelitian pendidikan. Bandung : Alfabeta.

[12] Onwuachu, Chidimma, W. \& Kanayo, C. (2015). Journal of Research in Pure and Applied Sciences. 5(1). 40-48.

[13] Purwati, Sunarno. W., Utomo, S. B. (2018). Jurnal Pendidikan IPA. 7(2). 182-189.

[14] Aini, N., Ashadi \& Nurhayati, N. D. (2014). Jurnal Pendidikan Kimia. 3(3). 98-104. 